\title{
IMPLEMENTATION OF COOPERATIVE LEARNING MODELS OF JIGSAW TYPE IN ECONOMIC LESSONS TO INCREASE STUDENT ACTIVITY AND LEARNING OUTCOMES
}

\section{Nyoman Yuliana Citra ${ }^{1}$}

${ }^{1}$ SMA Negeri Bali Mandara

\section{A R T I C L EI N F 0}

Article history:

Received 19 April 2018

Received in revised form

6 October 2018

Accepted 12 October 2018

Available online 20 October 2018

\section{Keywords:}

cooperative learning model by using jigsaw, learning activeness, and students' learning achievement.

\begin{abstract}
A B S T R A C T
This study is aimed to increase the activeness and the learning achievement through the implementation of cooperative learning model by using jigsaw on the Economy subject of the tenth grade students at IPS 1 class of SMA Negeri Bali Mandara academic year 2017/2018. The data was collected by using observation method and written test. Afterwards, the data was analyzed by using the quantitative descriptive analysis. The result of this study showed that: (1) the implementation of cooperative learning model by using jigsaw on the Economy subject had increased the students' learning activeness of the tenth grade students at IPS 1 class of SMA Negeri Bali Mandara academic year 2017/2018. This result was proven by the average score of the students' learning activeness from the cycle I was 3,02 which belongs to active category and the score on the cycle II was 3,59 which is also in the category of active. (2) The implementation of cooperative learning model by using jigsaw on the Economy subject has increased the students' learning achievement of the tenth grade students at IPS 1 class of SMA Negeri Bali Mandara academic year 2017/2018. The result showed that the students' learning completeness on the cycle I was $43,48 \%$ with the class average score was 76,88 and the students' learning completeness on the cycle II had increased up to $100,00 \%$ with the class average score was 86,31 .
\end{abstract}




\section{Introduction}

Many efforts have been made by various parties to improve the quality of education. The business includes the enactment of Law No. 20 of 2003 concerning the National Education System, upgrading teachers about the teaching and learning process, procurement of teaching materials and reference books, and holding activities in the MGMP.

In fact, the business has not achieved maximum results. This can be seen from the distribution of Final Assessment scores in Semester I Economics subjects in class X IPS 1 Bali Mandara Senior High School 2017/2018 academic year which are presented in table 1.1 below

Table 1. Distribution of Assessment Values Final Semester I

\begin{tabular}{llll}
\hline Interval & Category & $\begin{array}{l}\text { Number of } \\
\text { students }\end{array}$ & Percentage \\
\hline $0-40$ & Sangat Kurang & 0 & $0,00 \%$ \\
$41-60$ & Kurang & 7 & $30,43 \%$ \\
$61-70$ & Cukup & 9 & $39,13 \%$ \\
$71-85$ & Baik & 7 & $30,43 \%$ \\
$86-100$ & Baik Sekali & 0 & $0,00 \%$ \\
Sum & & $\mathbf{2 3}$ & $\mathbf{1 0 0 , 0 0 \%}$ \\
\hline
\end{tabular}

(Source: Economic subjects grade X IPS 1 document in Bali Mandara High School)

Based on Table 1 above, it can be seen that there are still students who scored in the less category as many as 7 people. This fact is quite alarming considering that the 2013 curriculum applied to education today requires a change in the learning process from the learning process which tends to be passive, theoretical, and teacher-centered into a learning process that is active, creative, and studentcentered. This is expected to have an effect on improving student learning outcomes. Based on observations, especially in class X IPS 1, Bali Mandara High School obtained an illustration, namely: (1) interest in learning Economics students are reduced due to student learning routines are crowded and students feel less motivated to learn; and (2) students tend to be passive in participating in learning activities.

Increasing student activity and learning outcomes can be done with a learning approach that can help teachers improve student understanding and self-confidence so students can be active in attending lessons. One of the efforts that can be done is by implementing cooperative learning. In cooperative learning students not only as objects but also as subjects who actively and creatively solve problems critically and beneficially. According to Stahl (in Trianto, 2007) states that cooperative learning is able to stimulate and arouse students' potential optimally in a learning atmosphere in social groups consisting of four to five people. In the cooperative learning model, the teacher no longer acts as the only source of learning but acts as a mediator, facilitator, dynamist, and learning manager. One of the learning models offered is cooperative jigsaw type.

Jigsaw coopertive learning was first developed by Elliot Aronson of the University of Texas. The jigsaw type coopertive learning model is a cooperative learning model where students learn in small groups consisting of four to five people with attention to heterogeneity, positive cooperation, and each member is responsible for studying certain problems of the material provided. Jigsaw type coopertive learning is designed to increase students' sense of responsibility for their own learning and other people's learning. Students not only learn the material provided, but they must also be ready to provide and teach the material to other group members. Thus, students are interdependent with one another and must cooperate cooperatively to study the material assigned. Through jigsaw type coopertive learning it will enable students who are clever (in this case students who have high academic abilities) can become tutors for students who are less intelligent (in this case students who have less academic ability).

Some other reasons that cause the jigsaw type coopertive learning model to be applied to economic learning are the absence of competition between students or groups. They work together to solve problems in overcoming different ways of thinking. Students in the group are responsible for mastering the learning material assigned to them and then teaching that part to other members. Students not only expect help from the teacher, students are also always motivated to learn quickly and accurately related to the material being studied.

By looking at the various advantages of the jigsaw type coopertive learning model that can provide an alternative for teachers in overcoming learning difficulties in the classroom, researchers feel the need to conduct research on the application of jigsaw type cooperative learning models on Economics subjects to 
improve the activeness and learning outcomes of IPS X students 1 Mandara Bali State High School $2017 / 2018$ academic year.

\section{Methods}

This study is a Classroom Action Research (CAR). This PTK leads to an action that is in the form of applying a learning model that aims to increase student activity and learning outcomes in a class that has problems in learning. This research was conducted at Mandara Bali State High School, namely in class X IPS 1 in the school year 2017/2018. Bali Mandara Public High School is located on Jalan Air Sanih Kubutambahan Village, Kec. Kubutambahan, Buleleng Regency. This study consisted of 2 cycles. The steps in each cycle consist of: (1) action plan, (2) implementation, (3) observation and evaluation, and (4) reflection.

The subjects in this study were class X IPS 1 Mandara Public High School with a total of 23 people consisting of 5 male students and 18 female students. The object in this study is the activeness and results of student learning by applying the jigsaw cooperative learning model in learning Economics. This research was conducted for 5 months from January to May 2018.

The types of data in this study are quantitative data and qualitative data. Quantitative data in the form of student learning outcomes with the application of a jigsaw cooperative learning model. While qualitative data is in the form of student learning activeness with the application of a jigsaw type cooperative learning model. The data sources used in this study are primary data, namely data that is directly obtained from research subjects in the form of data on student activity and learning outcomes with the application of a jigsaw type cooperative learning model. The data collected in this study is data on the activeness and learning outcomes of students with the application of a jigsaw type cooperative learning model. The instruments and data collection techniques used in this study are presented in Table.

Table 2 Instruments and Data Collection Techniques

\begin{tabular}{lllll}
\hline No. & Data & Data Sources & Method & Research Instruments \\
\hline 1 & $\begin{array}{l}\text { Students' Learning } \\
\text { Activeness }\end{array}$ & Students & Observation & Observation Sheet \\
2 & $\begin{array}{l}\text { Students' Learning } \\
\text { Outcomes }\end{array}$ & Students & Test & Pre test and daily test \\
\hline
\end{tabular}

Data about student learning activeness is obtained by using an observation sheet that contains student activities observed during the learning process. Student learning activeness is seen from six activities which consist of: (1) attendance, (2) courage to express opinions, (3) active questions, (4) active responses, (5) participation in group discussions, and (6) activeness when presentation. Each activity consists of five assessment criteria as shown in Table 3.

Table 3. Criteria for Assessing Student Learning Activity

\begin{tabular}{ll}
\hline Score & Criteria \\
\hline 1 & Never \\
2 & Rarely \\
3 & Sometimes \\
4 & Often \\
\hline 5 & Always \\
\hline
\end{tabular}

To measure student learning activeness, the instrument was used in the form of an observation sheet. The observation sheet consists of six activities, including: (1) attendance, (2) courage to express opinions, (3) active questions, (4) active responses, (5) participation in group discussions, and (6) activeness at presentation. Each of these activities has a score range of 1 to 5 . The steps of the analysis are as follows.

1) Calculate the average value of activity from the results of student learning activeness with the following formula. $\bar{X}=\frac{\sum X}{N}$

Notes: 
$\begin{array}{ll}\bar{X} & =\text { Average scores of students' activeness } \\ \sum X & =\text { Sum of students' activeness } \\ \mathrm{N}= & \text { Number of students }\end{array}$

2) Determine the category of the average value of student learning activeness. The range of average values and categories of student learning activeness can be seen in Table 4.

Table 4. Extensions of Average Values and Categories of Student Learning Activity

\begin{tabular}{ll}
\hline Interval & Category \\
\hline Nilai $\leq 1$ & Not active \\
$1<$ Nilai $\leq 2$ & Less active \\
$2<$ Nilai $\leq 3$ & Sufficient \\
$3<$ Nilai $\leq 4$ & Active \\
$4<$ Nilai $\leq 5$ & Very active \\
\hline
\end{tabular}

(Source: Baliastra, 2013:39)

o find out an increase in student learning outcomes in cycles I and II used the following formula.

1) Calculate the average value (mean) of student learning outcomes with the following formula.

$\bar{X}=\frac{\sum f X}{N}$

Notes:

$\bar{X} \quad=$ mean score

$\sum f X=$ Sum of scores

$\mathrm{N}=\quad$ Number of students

(Source: Sudjana, 2004:111)

The range of values and categories of student learning outcomes can be seen in Table 5 below.

Table 5. Range of Values and Categories of Student Learning Outcomes

\begin{tabular}{ll}
\hline Intervale & Category \\
\hline $0-40$ & Poor \\
$41-60$ & Less \\
$61-70$ & Sufficient \\
$71-85$ & Good \\
$86-100$ & Excellent \\
\hline
\end{tabular}

(Source: Baliastra, 2013:40)

2) Calculate learning completeness.

$K B=\frac{S}{N} x 100 \%$

Notes:

$\mathrm{KB}=$ Leatning completeness

$\mathrm{S} \quad=$ Number of completed students

$\mathrm{N}=\quad$ Number of students

(Source: Depdiknas dalam Baliastra, 2013:40)

The learning completeness value used in this study is the learning completeness value set at Bali Mandara High School as the place for conducting this study with a KKM score (Minimum Completion Criteria) is 75 . 


\section{Findings and Discussion}

Based on classroom action research conducted two meetings in the first cycle obtained the distribution of student learning activeness data presented in Table 6

Table 6. Distribution of Student Learning Activity Data in Cycle I

\begin{tabular}{lll}
\hline \multirow{2}{*}{ Category } & \multicolumn{2}{l}{$\begin{array}{l}\text { Students' Learning Activeness } \\
\text { First Meeting }\end{array}$} \\
& Number of students & $\begin{array}{l}\text { Second meeting } \\
\text { Number of students }\end{array}$ \\
\hline Poor activeness & 0 & 0 \\
Less active & 0 & 0 \\
Sufficient & 13 & 11 \\
Active & 10 & 12 \\
Very active & 0 & 0 \\
Sum & $\mathbf{2 3}$ & $\mathbf{2 3}$ \\
\hline
\end{tabular}

Based on Table 6 above, it can be seen that at the first meeting, there were 13 students (56.52\%) whose learning activeness was in the category of moderately active and 10 students (43.48\%) who were active learning is in the active category. At the second meeting, there were 11 students (47.83\%) whose learning activeness was in the fairly active category and 12 students (52.17\%) whose active learning was in the active category. In the first and second meetings there were no students who were in the category of very less active, less active, and very active.

Student learning outcomes on economic subjects with the application of the jigsaw type cooperative learning model can be seen from the results of tests conducted at the end of cycle I. The distribution of student learning outcomes data in the first cycle is presented in Table 7.

Table 7 Data Distribution of Student Learning Outcomes in Cycle I

\begin{tabular}{llll}
\hline Intervale & Category & Number of students & Percentage \\
\hline $0-40$ & Poor & 0 & $0,00 \%$ \\
$41-60$ & Less & 1 & $4,35 \%$ \\
$61-70$ & Suficient & 8 & $34,78 \%$ \\
$71-85$ & Good & 12 & $52,17 \%$ \\
$86-100$ & Excelent & 2 & $8,70 \%$ \\
Sum & & $\mathbf{2 3}$ & $\mathbf{1 0 0 , 0 0 \%}$ \\
\hline
\end{tabular}

From Table 7 above it can be seen that there are 1 student (4.35\%) who are in the less category, there are 8 students $(34.78 \%)$ who are in the sufficient category, there are 12 students $(52.17 \%)$ who in the good category, and there are 2 students $(8.70 \%)$ who are in the excellent category. Based on the results of data analysis, it is known that the average value of student learning outcomes is 76.88 which is in the good category. If the value of student learning outcomes is compared to the standard of completeness set at Bali Mandara High School where the KKM value is 75, then it can be seen the number of students who complete and who have not completed as shown in Table 8.

Table 8. Data Distribution of Student Learning Completeness in Cycle I

\begin{tabular}{lll}
\hline Category & Number of students & Percentage \\
\hline Completed & 10 & $43,48 \%$ \\
Uncompleted & 13 & $56,52 \%$ \\
Sum & $\mathbf{2 3}$ & $\mathbf{1 0 0 , 0 0 \%}$ \\
\hline
\end{tabular}

From Table 8, it can be seen that the number of students who have been completed by applying the jigsaw type cooperative learning model in the first cycle is 10 people $(43.48 \%)$ and the number of students who have not finished by applying the jigsaw cooperative learning model in cycle I is 13 people ( $56.52 \%$ ). If the percentage of the distribution of student learning completeness data in the first cycle is presented in graphical form can be seen in Figure 1. 


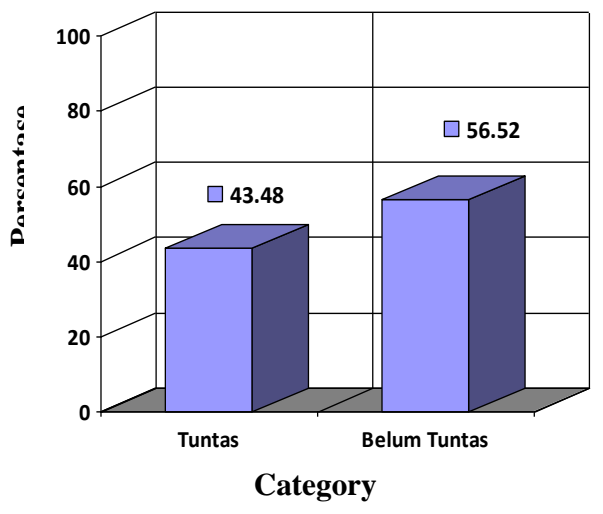

Figure 1 Percentage of Data Distribution of Student Learning Completeness in Cycle I

The implementation of the action in the first cycle shows that there are still problems faced by teachers related to economic learning activities by applying the jigsaw cooperative learning model, namely: (1) still lack of motivation for students to learn; (2) for learning activity students have obtained an increased average score for each meeting, but still not maximal; and (3) students are less enthusiastic in carrying out group discussions. During expert group discussions, students still tend to rely on friends who are considered smart to dominate the discussion.

Based on these problems, several actions were taken on the learning process by applying the jigsaw cooperative learning model, namely: (1) ways to motivate students by giving reinforcement or praise to students and by giving prizes to the most active students; (2) the teacher informs the results of the assessment in the first cycle, namely the value of student learning activeness and student learning outcomes in the hope that students become more active and eager to participate in learning activities so that the value increases; and (3) the teacher also informs the assessment criteria that will be used in the learning activities. This is done in the hope that students understand the assessment criteria so that they can take full advantage of learning activities.

Based on class action research in the second cycle, which was held twice, the students' learning activeness data was obtained as can be seen in Table 9

Table 9. Distribution of Student Learning Activity Data in Cycle II

\begin{tabular}{lll}
\hline \multirow{2}{*}{ Category } & \multicolumn{2}{l}{$\begin{array}{l}\text { Students' Learning Activeness Data } \\
\text { First meeting } \\
\text { Number of students }\end{array}$} \\
\hline Poor & 0 & $\begin{array}{l}\text { Second meeting } \\
\text { Number of students }\end{array}$ \\
Less active & 0 & 0 \\
Sufficient & 5 & 0 \\
Active & 12 & 4 \\
Very active & 6 & 12 \\
Sum & $\mathbf{2 3}$ & 7 \\
\hline
\end{tabular}

Based on table 4.4 above it can be seen that at the first meeting, there were 5 students (21.74\%) whose learning activeness was in the fairly active category, there were 12 students (52.17\%) whose learning activeness was in the active category, and there were 6 students (26.09\%) whose learning activeness is in the very active category. At the second meeting, there were 4 students $(17.39 \%)$ whose learning activeness was in the fairly active category, 12 students (52.17\%) whose learning activeness was in the active category, and there are 7 students (30.43\%) whose learning activeness is in the very active category. In the first and second meetings there were no students in the category of very less active and less active.

Student learning outcomes on economic subjects with the application of the jigsaw type cooperative learning model can be seen from the results of the tests conducted at the end of the second cycle. The distribution of student learning outcomes data in cycle II is presented in Table 10 
Table 10 Data Distribution of Student Learning Outcomes in Cycle II

\begin{tabular}{llll}
\hline Intervale & Category & Number of students & Percentage \\
\hline $0-40$ & Poor & 0 & $0,00 \%$ \\
$41-60$ & Less & 0 & $0,00 \%$ \\
$61-70$ & Sufficient & 0 & $0,00 \%$ \\
$71-85$ & Good & 15 & $65,22 \%$ \\
$86-100$ & Excellent & 8 & $34,78 \%$ \\
Sum & & $\mathbf{2 3}$ & $\mathbf{1 0 0 , 0 0 \%}$ \\
\hline
\end{tabular}

From Table 10 above it can be seen that there are 15 students (65.22\%) who are in the good category and there are 8 students (34.78\%) who are in the excellent category. Based on the results of data analysis it can be seen that the average value of student learning outcomes is 86.31 which is in the excellent category. If the value of student learning outcomes is compared to the standard of completeness set at Bali Mandara High School where the KKM value is 75, then it can be seen the number of students who have completed and who have not completed as shown in Table 11.

Table 11. Data Distribution of Student Learning Completeness in Cycle II

\begin{tabular}{lll}
\hline Category & Number of students & Percentage \\
\hline Completed & 23 & $100,00 \%$ \\
Uncompleted & 0 & $0,00 \%$ \\
Sum & $\mathbf{2 3}$ & $\mathbf{1 0 0 , 0 0 \%}$ \\
\hline
\end{tabular}


From Table 11, it can be seen that the number of students who have completed using the jigsaw cooperative learning model in cycle II is 23 people $(100.00 \%)$ and there are no students who have not finished. If the percentage of the distribution of student learning completeness data in cycle II is presented in graphical form can be seen in figure 2.

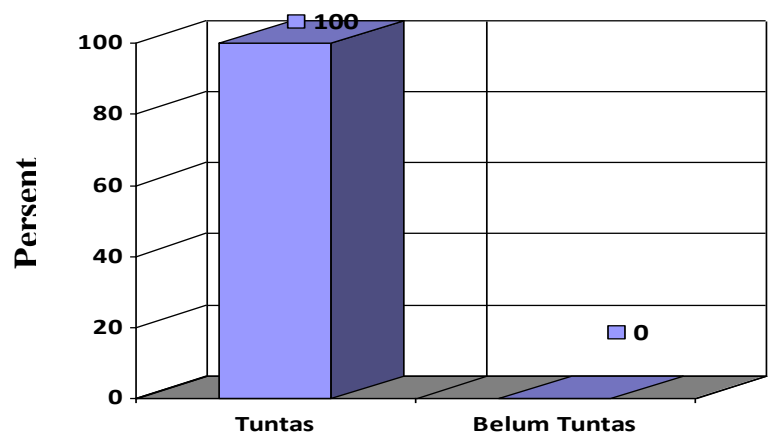

Category

Figure 2 Percentage of Data Distribution of Student Learning Completeness in Cycle II

After making improvements in the second cycle, it can be seen that there is an increase in the acquisition of student activeness and learning outcomes. In the implementation of the action in cycle II can be observed matters relating to the application of the type of jigsaw cooperative learning model, namely: (1) in the implementation of the second cycle, students have been able to follow the jigsaw cooperative learning model applied in learning activities. Students are active in seeking information and building their own understanding regarding the material discussed. (2) The average value for student learning activity has increased. All students have prepared themselves well before attending the lesson. (3) All groups have been able to conclude and present the results of the discussion properly. (4) Students who have less ability are more helpful in solving the problems they face in discussions because the information conveyed by students who have better abilities has been able to explain information clearly so that it is easy to understand.

Based on the results of the research in the first cycle and second cycle, it can be seen that the activity and learning outcomes of students with the application of the jigsaw type cooperative learning model has increased. By applying the jigsaw type cooperative learning model, students can learn and explain the subject matter to other friends well so that students can understand the subject matter easily. In addition, students have full responsibility for the tasks given by the teacher so that students can develop their potential to the fullest.

Based on the research carried out as much as two cycles showed an increase in the activeness and learning outcomes of students on Economics subjects with the application of the jigsaw type cooperative learning model. The average value of student learning activeness in cycles I and II can be seen in figure 3 below.

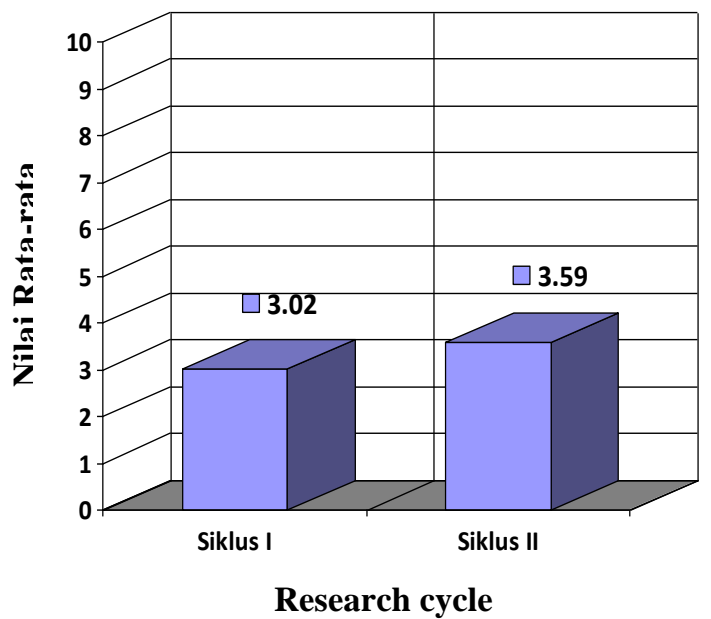


Figure 3 Average Value of Student Learning Activity in Cycles I and II

From the picture it can be seen that there is an increase in student learning activeness in Economics subjects with the application of the jigsaw type cooperative learning model in cycles I and II. In Cycle I, for the first meeting the average value of student learning activity was 3.00 and in the second meeting it increased to 3.04 so that if the average value of student learning activity was sought in the first cycle of 3.02 in the category active. Likewise in the second cycle, for the first meeting the average value of student learning was 3.46 and the second meeting increased to 3.71 so that if the average value of student learning activeness was searched for in the second cycle of 3.59 which was in the active category.

In the first cycle, student learning activeness was getting better with the application of the jigsaw type cooperative learning model. This can be seen from: (1) students already have awareness as an expert in accordance with the submission or topic discussed, it is then informed to friends in the original group; (2) students have shown their activeness by daring to appear in front of the class to present the results of the discussion and express their opinions; and (3) students are motivated to ask questions at the presentation and have the ability to answer these questions. Based on the results of the assessment in the first cycle, it can be seen that students' learning activeness is in the active category.

In cycle II, almost all students have dared to express their opinions, present the results of their discussions, and actively provide questions and input during the presentation activities. Based on the results of the assessment in the second cycle, it can be seen that students' learning activeness is in the active category. Based on the results of these studies, it can be concluded that the application of the jigsaw type cooperative learning model can be an alternative to be applied to economic subject learning activities in the classroom because the learning model in general has succeeded in increasing student learning activeness.

From the results of research that has been done, it can be seen that the application of the jigsaw type cooperative learning model can improve student learning outcomes in Economics subjects. In the jigsaw type cooperative learning model there are student interactions in learning that make it easier for students to understand the subject matter and get the desired results. Student learning outcomes value data clearly shows an increase in cycles I and II. In the first cycle, student learning outcomes increased with learning completeness by $43.48 \%$ with a class average value of 76.88 . In the second cycle, student learning outcomes also increased with learning completeness of $100.00 \%$ with a class average value of 86.31. When viewed from cycles I and II, there is an increase in student mastery learning by $56.52 \%$ with an increase in the grade average value of 9.43. This means that there is an increase in understanding of the concepts of the material studied by applying the jigsaw type cooperative learning model in cycles I and II. Based on this, it can be seen that the application of the jigsaw type cooperative learning model can improve student learning outcomes in Economics subjects in class X IPS 1 Bali Mandara High School $2017 / 2018$ academic year.

\section{Conclusion}

Based on the results of the research and discussion conducted, a number of things can be summarized as follows.

(1) The application of the jigsaw type cooperative learning model on economic subjects can improve the learning activeness of X IPS 1 students in Bali Mandara High School in the academic year $2017 / 2018$. These results are indicated by the average value of student learning activity in the first cycle of 3.02 which is in the active category and the average value of student learning activeness in the second cycle is 3.59 which is in the active category.

(2) The application of the jigsaw type cooperative learning model on Economics subjects can improve the learning outcomes of X IPS 1 students in Bali Mandara High School in the academic year $2017 / 2018$. These results are shown by student learning completeness in the first cycle of $43.48 \%$ with a class average value of 76.88 and student learning completeness in the second cycle increased to $100.00 \%$ with a class average value of 86.31 .

Based on the conclusions described above, suggestions can be made regarding the results of this study, as follows:

(1) Economics subject teachers to apply the jigsaw cooperative learning model in economic learning activities. By applying the jigsaw type cooperative learning model, the learning activities carried out become more varied so that they can increase student activity and learning outcomes. 
(2) It is expected that the next researcher will carry out further research by applying the jigsaw type cooperative learning model on different subjects so that it can be known the effect of applying the jigsaw type cooperative learning model in the learning activities.

\section{References}

Ada, I Komang. 2014. Penerapan Model Pembelajaran Kooperatif Tipe Jigsaw pada Mata Pelajaran Geografi untuk Meningkatkan Aktivitas dan Hasil Belajar Siswa Kelas X2 SMA Negeri 1 Bebandem Tapel. 2013/2014. Skripsi. Jurusan Pendidikan Geografi, Universitas Pendidikan Ganesha.

Arikunto, S. 2006. Manajemen Penelitian. Jakarta: PT. Rineka Cipta.

Baliastra, Nyoman. 2013. Penerapan Model Pembelajaran Kooperatif Tipe Jigsaw Untuk Meningkatkan Keaktifan dan Hasil Belajar Mata Pelajaran Ekonomi Siswa Kelas XA SMAN 1 Kubutambahan Tahun Ajaran 2012/2013. Skripsi. Jurusan Pendidikan Ekonomi, Universitas Pendidikan Ganesha.

Dimyati dan Mudjiono. 1994. Belajar dan Pembelajaran. Jakarta: PT. Rineka Cipta.

Lie, Anita. 2002. Cooperative Learning. Jakarta: PT. Grasindo.

Mayani, A. A. Istri Trisnia. 2013. Meningkatkan Hasil Belajar Siswa dengan Penggunaan Model Pembelajaran Kooperatif Tipe Jigsaw pada Mata Pelajaran PKn di Kelas VIII B SMP Negeri 1 Payangan. Skripsi. Jurusan Pendidikan Pancasila dan Kewarganegaraan, Universitas Pendidikan Ganesha.

Sandiasih. 2008. Penerapan Model Pembelajaran Kooperatif Tipe Jigsaw untuk Meningkatkan Hasil Belajar IPS Siswa Kelas VII A Semester 2 SMP Negeri 2 Selat-Karangasem Bali Tahun 2007/2008. Skripsi. Jurusan Pendidikan Ekonomi, Universitas Pendidikan Ganesha.

Sanjaya, Wina. 2006. Strategi Pembelajaran: Berorientasi Standar Proses Pendidikan. Jakarta: Penerbit Kencana.

Slameto. 2003. Belajar dan Faktor-faktor yang Memengaruhinya. Jakarta: PT. Rineka Cipta.

Solihatin, Etin dan Raharjo. 2007. Cooperatif Learning: Analisis Model Pembelajaran IPS. Jakarta: PT. Bumi Aksara.

Sudijono, Anas. 2005. Pengantar Evaluasi Pendidikan. Jakarta: PT. Raja Grasindo Persada.

Sukidin, dkk. 2008. Manajemen Penelitian Tindakan Kelas. Surabaya: Penerbit Insan Cendikia.

Sudjana, Nana. 2004. Penilaian Hasil Proses Belajar Mengajar. Bandung: PT. Remaja Rosdakarya.

Suprijono, Agus. 2009. Cooperative Learning: Teori dan Aplikasi PAIKEM. Yogyakarta: Penerbit Pustaka Pelajar.

Trianto. 2007. Model-model Pembelajaran Inovatif Berorientasi Konstruktivisme. Jakarta: Penerbit Prestasi Pustaka Publisher.

2009. Mendesain Model Pembelajaran Inovatif-Progresif: Konsep, Landasan, dan Implementasinya pada Kurikulum Tingkat Satuan Pendidikan (KTSP). Jakarta: Penerbit Kencana 